\title{
Høytpresterende elevers opplevelse av naturfagundervisning i prestasjonslike elevgrupper på ungdomstrinnet
}

\author{
Bård Knutsen*, \\ Program for lererutdanning, NTNU, Trondheim, Norge
}

\begin{abstract}
Sammendrag
Denne studien søker å finne svar på hvordan høytpresterende elever på ungdomstrinnet opplever og responderer på naturfagundervisning i prestasjonslike elevgrupper. Over en periode på seks uker ble to parallelle intervensjoner gjennomført ved en ungdomsskole i Midt-Norge. Intervensjonene var: i) inndeling i prestasjonslike elevgrupper, og ii) økt bruk av utforskende arbeidsmåter.

Analysene av det kvantitative datamaterialet viser at intervensionene hadde kun mindre innvirkning på elevenes selvoppfatning og motivasjon, men var av større betydning for elevenes opplevelse av trivsel og motivasjon. De kvalitative dataene indikerer at medeleveffekter, gjort mulig gjennom tilrettelegging for samarbeid og kommunikasjon elevene i mellom, var viktigste årsak til økt trivsel og læring i denne studien. Det ble ikke påvist like tydelige tilpasningseffekter. Funn i studien indikerer at lærernes undervisningspraksis, og fag- og undervisningsorientering, er av stor betydning for hvordan læreren evner å tilpasse undervisningen slik at elevene får et optimalt utbytte av naturfagundervisning i prestasjonslike elevgrupper på ungdomstrinnet.
\end{abstract}

Nøkkelord: Nivådeling $i$ naturfag; selvoppfatning; trivsel og laring; didaktisk kontrakt

\begin{abstract}
The aim of this intervention is to study how high-ability students in secondary schools experience and respond to science education in homogenous-performing groups. For the period of six weeks there were conducted two parallel interventions at a lower secondary school in central Norway. These interventions were: i) division of students in homogenous-performing groups, and ii) increased use of inquiry-based science teaching.

The quantitative data show a minor increase in the high performing students' self-concept, but no change in motivation as a result of the intervention. However, the students reported major changes in the sense of well-being and learning. The qualitative data indicate that peer effects were the main reason for the increased sense of well-being and learning in this study. This appears to be made possible through enabling collaboration and communication between students. The analysis points to the science teachers' teaching practices, subject, and teaching
\end{abstract}

^Korrespondanse: Bård Knutsen, Jonsvannsveien 82, PLU, NTNU, 7494 Trondheim. E-post: Bard.knutsen@plu.ntnu.no 
orientation as key factors to consider optimizing the efficiency gains (direct tracking effect) in homogenous-performing groups.

Keywords: Differentiated groups at lower secondary level; self-concept; well-being and learning; science; didactic contract

Received: September 2015; Accepted: January 2016; Published: April 2016

\section{Innledining}

I Norge har det vært en utbredt antakelse at høytpresterende elever klarer seg på egen hånd, og av den grunn blir det sjelden truffet spesielle tiltak for disse elevene (Utdannings- og forskningsdepartementet, 2003). Denne praksisen har tidvis vært kritisert, men uten at det har bidratt til store endringer (Birkemo, 2002). Høytpresterende elever har, på lik linje med andre elever, behov for tilpasset opplæring. I følge Rimm (2008) har høytpresterende elever behov for et stimulerende læringsmiljø, hvor deres kognitive evner blir utfordret og sosiale behov ivaretatt, for å oppnå optimal kognitiv utvikling. Kunnskapsdepartementet (2010, s. 68) definerer læringsmiljø som de samlede, kulturelle, relasjonelle og fysiske forhold på skolen som har betydning for elevenes laring, helse og trivsel.

Renzulli og Renzulli (2010) hevder at skolene bør utvikle og ta i bruk læringsaktiviteter som virker utviklende på elevenes begavelser. Dette kan skje ved at skolene legger til rette for at elevene møter induktiv læring. Induktiv læring har tre kjennetegn: i) elevene har eieforhold til problemstillingen, ii) elevene arbeider undersøkende eller kreativt på lignende måte som profesjonelle yrkesutøvere arbeider med samme type problemstillinger, og iii) oppgavene skal føre til resultater. Induktiv tilnærming til læring i naturfag har mange likhetstrekk med rammene for utforskende naturfagundervisning (Knutsen, 2015b). En overgang fra deduktiv til induktiv læring beskriver Renzulli og Renzulli (2010) som en berikelse av undervisningen. Læreren blir mer veileder enn ren kunnskapsformidler, og elevene får større handlingsrom og økt autonomi.

Internasjonal forskning gir ikke klare svar på om nivådeling i prestasjonslike elevgrupper er et egnet organisatorisk tiltak for å møte læringsbehovene for de høytpresterende elevene (Adams-Byers, Whitsell, \& Moon, 2004). Denne studien tar utgangspunkt $\mathrm{i}$ at organisatorisk differensiering kan ha både positive og negative effekter på elevers læringsutbytte. Økt omfang av organisatorisk differensiering i den norske skolekonteksten forutsetter løsninger som demper de negative konsekvensene og fremmer de positive. Problemstillingen som ligger til grunn for denne artikkelen er:

Hvordan opplever og responderer høytpresterende tiendetrinnselever på naturfagundervisning i prestasjonslike elevgrupper?

For å svare på dette spørsmålet blir kvantitative og kvalitative data presentert og drøftet opp mot relevant teori og forskningsresultater. 


\section{Teori}

Læring er en aktiv prosess som krever egeninnsats (Gagné, 2010) og påvirkes av blant annet den lærende sin selvoppfatning og den didaktiske kontrakten for undervisning.

\section{Elevers selvoppfatning}

Selvoppfatning handler om elevers tanker om seg selv og hvordan disse påvirker læring og kognitiv utvikling (Harter, Fischer, Harter \& Serwator, 1999). Det et menneske føler, tror og vet om seg selv vil påvirke dets muligheter for læring og utvikling i vid forstand. Mennesker vil alltid handle ut i fra en forestilling om hva slags person de opplever å være (Rosenberg, 1979).

Skaalvik og Skaalvik (2005) peker på at en persons selvoppfatning er kontekstavhengig og utvikler seg ved at vedkommende hele tiden vurderer seg selv i ulike situasjoner, og at den vil variere fra situasjon til situasjon og fra en livsfase til en annen. I vår søken etter å finne ut hvordan vi klarer oss i livet, måler vi både verbale og ikkeverbale reaksjoner fra mennesker rundt oss og gjennom sosiale sammenligninger. Mennesket har behov for å vurdere seg positivt og vil ta i bruk beskyttelsesmekanismer dersom selvverdet blir truet.

Elever på ungdomstrinnet vil sammenligne sine prestasjoner med sine egne standarder - for eksempel sammenligner de prestasjoner i naturfag med prestasjoner i andre fag. Samtidig får sosiale sammenlikninger mer innflytelse, og dermed betydning for elevenes selvoppfatning i fagene på skolen, med økende alder. Skaalvik og Skaalvik (2005) skiller mellom gruppesammenlikning og individuell sammenlikning. Mens gruppesammenlikning er påtvunget elevene gjennom gruppesammensetningen, er individuell sammenlikning frivillig, fordrer aktiv sammenligning fra elevenes side, og de må selv velge hvem de skal sammenligne seg med.

Elevers selvoppfatning blir påvirket av medelevenes prestasjoner (Pintrich \& Schunk, 2002). Elever som er faglig sterke i naturfag vil for eksempel ha høyere selvoppfatning $\mathrm{i}$ en gjennomsnittlig naturfagklasse enn elever med samme kunnskapsnivå i en høytpresterende klasse. Marsh (1990) kaller denne effekten for «Big fish - little pond» -effekten (BFLPE). Deltakelse i opplegg for høytpresterende elever vil, ut fra denne teorien, øke risikoen for redusert selvoppfatning i faget. Teorien predikerer med andre ord negative effekter på høytpresterende elevers læringsutbytte ved overgang til prestasjonslike elevgrupper.

\section{Didaktisk kontrakt og endringsmotstand}

I all institusjonalisert undervisning hvor en lærer underviser en klasse over en lengre tidsperiode, utvikles et spesielt forhold mellom lærer og elever gjennom deres felles møte med faget. Dette forholdet kan beskrives metaforisk ved å omtale det som en didaktisk kontrakt for undervisningen (Brousseau, 1984). Blomhøj (1994) viser til at etableringen av didaktisk kontrakt er både en følge av undervisningen og en nødvendig forutsetning for at undervisningen skal kunne gjennomføres. I det lange løp påvirker den didaktiske kontrakten både elevenes opplevelse av faget og deres holdning til læring. Tilsvarende påvirkes lærerens forståelse av hva undervisning i faget innebærer. 
Etableringen av en didaktisk kontrakt kan ifølge Blomhøj (1994) ha flere konsekvenser for elevenes læring og muligheter for utviklingsarbeid i skolen. For det første kan elevene være mer opptatt av å møte lærernes forventninger enn å forstå fagstoffet. For det andre kan kontrakten være til hinder for endret undervisningspraksis. Elevene vil kunne føle frustrasjon over nye arbeidsformer selv om de innledningsvis kan framstå som engasjerte og gjøre som de får beskjed om. Det er gjennom dialogen mellom lærer og elev den didaktiske kontrakten kan utfordres og eventuelt endres. Dialogen er med andre ord av stor betydning for å lykkes med et utviklingsarbeid hvor den didaktiske kontrakten er involvert. Blomhøj (1994) hevder at elever gjennom tilpasset dialog med læreren vil kunne endre læringspraksis i retning av en mer undrings- og læringsorientert arbeidsform.

\section{Metode}

I denne studien er både kvalitativ og kvantitativ tilnærming benyttet for å avdekke høytpresterende elevers opplevelse av og respons på naturfagundervisning i prestasjonslike elevgrupper. Når komplekse fenomener skal undersøkes, kan ulike innfallsvinkler være hensiktsmessig (Creswell \& Clark, 2011). Den kvantitative tilnærmingen gir et bilde av hvordan organisatorisk differensiering av elever i prestasjonslike elevgrupper påvirker elevenes selvoppfatning, motivasjon og læringsmiljø. Den kvalitative tilnærmingen utfyller og beriker disse temaene ytterligere gjennom elevenes tanker, erfaringer og refleksjoner. Denne måten å kombinere kvalitativ og kvantitativ tilnærming betegnes «mixed-methods design» (Creswell \& Clark, 2011). Ved bruk av mixed-methods design kan den kvalitative metodens svakheter i noen grad oppveies av styrkene ved den kvantitative metoden og motsatt (Creswell \& Clark, 2011).

\section{Forskningsdesign}

To ulike intervensjoner ble gjennomført ved en ungdomsskole i Midt-Norge. Intervensjonsperioden varte i seks uker våren 2009. Den første intervensjonen var reorganisering av skolens tiendetrinnselever $\mathrm{i}$ fire prestasjonslike elevgrupper i naturfag. Inndelingen av elevene ble gjort på grunnlag av elevenes terminkarakter, og i denne studien er fokuset på elevene $\mathrm{i}$ de to høyest presterende elevgruppene, det vil si elever med terminkarakter fire eller bedre i naturfag. Ved rangering av de høytpresterende elevene i nest høyest (gruppe C) og høyest presterende (gruppe D), ble lærernes subjektive vurderinger og elevenes egne vurderinger også tillagt vekt. Gruppe C bestod av totalt 28 elever og gruppe D av totalt 27 elever. To lærere underviste hver sin elevgruppe. Frank underviste D-elevene og Mona underviste Celevene. På grunn av at elevene ble inndelt i prestasjonslike elevgrupper og elevenes opprinnelige to naturfaglærere underviste dem gjennom intervensjonsperioden, ble lærerbytte en nødvendig konsekvens for halvparten av elevene.

Den andre intervensjonen var kompetanseheving og veiledning av lærerne i bruk av utforskende arbeidsmåter i naturfagundervisningen. Intervensjonen var forankret i litteratur som anbefaler utforskende naturfagundervisning for høytpresterende 


\section{Bård Knutsen}

elever (Renzulli \& Renzulli, 2010). Målet var økt bruk av slike elevaktiviteter. Det var forsker selv som gjennomførte kompetansehevingen og veiledningen av lærerne.

\section{Datainnsamling}

Elevene svarte på en pretest som bestod av trettito spørsmål som omhandlet informasjon om elevene, interesse, holdninger, læring, undervisningspraksis og mestringsopplevelser knyttet til naturfag. I tillegg ble det gjennomført en posttest like før intervensjonsperioden ble avsluttet. Denne bestod av nitten spørsmål, hvorav femten spørsmål også ble stilt i pretesten. Dette gjorde det mulig å sammenligne elevenes svar før og etter nivådeling og avdekke eventuelle effekter av intervensjonene. Spørsmålene ble i all hovedsak hentet fra «Elevspørreskjema PISA 2006». Disse er omfattende utprøvd og validitets- og reliabilitetstestet (alfa rundt eller over $0,7)$, og variablene har høy indre konsistens og er forankret i teori og empiri (Kjærnsli, Lie, Olsen \& Roe, 2007).

Spørreskjemaene inneholdt en rekke enkeltvariabler. De fleste inngikk i samlevariabler fordelt på fire ulike tema. Organiseringen av samlevariabler og tema er sammenfallende med analysene gjort i PISA 2006 (Kjærnsli m.fl., 2007). Med utgangspunkt i spørsmålene i spørreskjemaene ble det beregnet gjennomsnittskår for ti ulike samlevariabler. De fire temaene med tilhørende samlevariabler er som følger:

- Lærernes undervisningspraksis (Bruk av samtale, Praktisk elevarbeid, Utforsking av egne ideer og Anvendelser av naturfaget)

- Elevenes selvoppfatning (Selvvurdering og Mestringsforventning)

- Elevenes indre motivasjon (Interessebasert motivasjon og Generell interesse for å lære naturfag)

- Elevenes ytre motivasjon (Framtidsrettet motivasjon og Instrumentell motivasjon).

Kun svarene til elever som responderte på både pre- og posttest, der dette var etterspurt, er med i det kvantitative datagrunnlaget. 25 elever i hver prestasjonsgruppe svarte på begge spørreundersøkelsene (pre- og posttest) og utgjør det kvantitative utvalget. Det var 7 gutter og 18 jenter i gruppe C og 12 gutter og 13 jenter i gruppe D.

Posttesten inneholdt, i tillegg til PISA-spørsmålene, fire egenutviklede spørsmål om elevenes opplevelse av trivsel og læring i forkant av og underveis i intervensjonsperioden der elevene ble bedt om å begrunne sine vurderinger. De skriftlige begrunnelsene inngår $i$ det kvalitative datamaterialet. Det øvrige kvalitative datagrunnlaget består av transkripter fra fire semistrukturerte fokusgruppeintervju gjennomført i etterkant av forsøksperioden og fungerte som oppfølging av den kvantitative datainnsamlingen.

\section{Analyse}

Mixed-methods design genererer både kvalitative og kvantitative data og forutsetter derfor ulike tilnærmingsmåter. På grunn av få informanter ble de kvantitative dataene deskriptivt 
analysert uten en omfattende statistisk analyse og bruk av signifikansnivå for å påvise endringer. De kvalitative dataene ble analysert ved bruk av analyseverktøy utviklet innenfor konstant komparativ metode. Dette er en analysemetode som Postholm (2005) hevder er velegnet for alle kvalitative studier hvor koding og kategorisering av datamateriale er sentralt.

Det kvantitative datagrunnlaget ble generert fra spørreskjemaene. Den kvalitative analysen avdekket tidlig $i$ analyseprosessen lærernes innvirkning på elevenes opplevelse av og respons på intervensjonene, noe det er tatt hensyn til i det videre analysearbeidet. Tabell 1 viser et eksempel på en endelig resultatoversikt med synliggjøring av hvilke elever som byttet lærer og ikke i løpet av intervensjonsperioden.

Eksemplet viser elevenes rapportering for temaet lerernes undervisningspraksis, i forkant av og underveis i intervensjonsperioden, fordelt på de tilhørende samlevariablene. Verdien «1» indikerer at den beskrevne undervisningsaktiviteten gjennomføres aldri eller nesten aldri, mens verdien «4» indikerer at den giennomføres $i$ alle timer. Tilsvarende resultattabeller ble utarbeidet for alle tema og variabler som ble målt $\mathrm{i}$ denne studien. Nest-høyest-presterende elever undervist av Mona i forkant av intervensjonsperioden fikk beskrivelsen C-elever uten lærerbytte, mens de som opprinnelig ble undervist av Frank, fikk beskrivelsen C-elever med lærerbytte. Tilsvarende ble giort for de høyest presterende elevene. De som opprinnelig ble undervist av Mona, fikk beskrivelsen D-elever med lærerbytte, mens de som opprinnelig ble undervist av Frank, fikk beskrivelsen D-elever uten lærerbytte.

Spørsmål som angikk elevenes opplevelse av trivsel og læring, i forkant av og underveis $\mathrm{i}$ intervensjonsperioden, ble behandlet som separate variabler. Elevene rapporterte opplevelse av trivsel og læring ut fra en firedelt skala, hvor verdien 4 indikerte svært høy trivsel/læring og verdien 1 indikerte lav trivsel/læring.

Tabell 1. Høytpresterende elevers opplevelse av undervisningspraksis i naturfag. Avvik i differanseverdier skyldes avrunding.

\begin{tabular}{|c|c|c|c|c|c|c|c|c|c|c|c|c|c|}
\hline \multirow[b]{3}{*}{ Elever } & \multirow[b]{3}{*}{$\mathrm{n}$} & \multicolumn{12}{|c|}{ Undervisningspraksis i naturfag } \\
\hline & & \multicolumn{3}{|c|}{ Samtale } & \multicolumn{3}{|c|}{$\begin{array}{c}\text { Praktisk } \\
\text { elevarbeid }\end{array}$} & \multicolumn{3}{|c|}{$\begin{array}{l}\text { Utforsking av } \\
\text { egne ideer }\end{array}$} & \multicolumn{3}{|c|}{ Anvendelser } \\
\hline & & Pre & Post & Diff & Pre & Post & Diff & Pre & Post & Diff & Pre & Post & Diff \\
\hline C-elever uten lærerbytte & 14 & 2,4 & 3,0 & 0,6 & 1,7 & 2,1 & 0,5 & 1,5 & 1,6 & 0,1 & 2,3 & 2,5 & 0,2 \\
\hline C-elever med lærerbytte & 11 & 2,7 & 3,1 & 0,4 & 1,7 & 2,3 & 0,7 & 1,4 & 1,7 & 0,3 & 2,3 & 2,3 & 0,0 \\
\hline C-elever samlet & 25 & 2,6 & 3,1 & 0,5 & 1,7 & 2,2 & 0,5 & 1,5 & 1,7 & 0,2 & 2,3 & 2,4 & 0,1 \\
\hline D-elever med lærerbytte & 13 & 2,6 & 3,2 & 0,6 & 1,7 & 2,6 & 0,9 & 1,4 & 1,8 & 0,4 & 2,3 & 2,4 & 0,1 \\
\hline D-elever uten lærerbytte & 12 & 2,3 & 3,1 & 0,8 & 1,8 & 2,2 & 0,4 & 1,4 & 1,5 & 0,0 & 2,8 & 2,5 & $-0,4$ \\
\hline D-elever samlet & 25 & 2,5 & 3,2 & 0,7 & 1,8 & 2,4 & 0,7 & 1,4 & 1,7 & 0,2 & 2,6 & 2,4 & $-0,1$ \\
\hline C og D-elever samlet & 50 & 2,5 & 3,1 & 0,6 & 1,7 & 2,3 & 0,6 & 1,5 & 1,7 & 0,2 & 2,4 & 2,4 & 0,0 \\
\hline
\end{tabular}




\section{Bård Knutsen}

\section{Empiri}

Analysen av de kvalitative dataene, med støtte i kvantitative, avdekket følgende tre forhold av betydning for denne studiens problemstilling: i) Lærernes undervisningspraksis, ii) læringsmiljø og iii) elevers selvoppfatning, motivasjon, trivsel og læring. Disse tre forholdene er gjensidig avhengig av hverandre. Dette er ikke uventet, siden individers handlinger framkommer i interaksjon og samspill med omgivelsene og tolkningen av disse.

\section{Endring i undervisningspraksis}

Den kvantitative analysen av temaet lerernes undervisningspraksis viser at elevene $\mathrm{i}$ snitt opplevde økt bruk av Samtale og Praktisk elevarbeid i løpet av intervensjonsperioden. Utforsking av egne ideer og Anvendelser av faget $i$ dagliglivet virket å være ubetydelig påvirket av intervensjonene.

Endringene i undervisningspraksis ble gjennomgående positivt mottatt av elevene. Særlig C-elevene ga uttrykk for at de satte pris på økningen i bruk av praktiske elevaktiviteter (lærte annerledes og artigere). En C-elev sa det på denne måten: «Når du sitter og leser, så blir det fort kjedelig. Hvis du er i aktivitet og driver med det så blir det artigere».

Enkelte elever antydet likevel at det ble litt for mange praktiske elevaktiviteter. Det var særlig D-elevene som signaliserte dette. Et annet moment ved bruk av praktiske elevaktiviteter, påpekt av en D-elev uten lærerbytte, var elevenes ønske om å koble teori og praksis. Eleven ønsket at læreren hadde gjennomgått og oppsummert i plenum hva de hadde kommet fram til og ikke bare overlot dette til elevene selv:

Jeg synes at etter forsøkene så kunne vi hatt gjennomgang av forsøkene, en oppsummering liksom, om hva vi hadde kommet fram til. (...) Det er veldig bra at vi har sånne forsøk og sånn, men at vi hadde liksom begge deler. Det hadde vært bra.

Den kvalitative analysen av fokusgruppeintervjuene støttet hovedfunnet i den kvantitative, at undervisningspraksisen var endret i retning av økt bruk av samtale og praktisk elevarbeid, noe blant annet følgende utsagn fra en C-elev med lærerbytte viser: «Det er en annerledes måte å lære på enn det vi gjør til vanlig - da sitter vi bare på plassene våre og skriver».

\section{Intervensjonenes innvirkning på elevenes læringsmiljø}

Den kvalitative analysen avdekket at elevenes medelever, hvem de var og deres kvaliteter (medeleveffekt), hadde betydning for elevenes opplevelse av å bli gruppert i prestasjonslike elevgrupper.

Flertallet av elevene $\mathrm{i}$ disse to gruppene ga uttrykk for at de foretrakk å være gruppert med jevnbyrdige medelever. Dette ble blant annet begrunnet i glede over å tilhøre gruppen høytpresterende elever, at det var positivt å bli kjent med nye personer, mer arbeidsro, flere å spørre om hjelp, mulighet for å forbedre karakterene 
og at de kunne stole på at medelevene gjorde det de skulle. En D-elev beskrev de positive medeleveffektene på denne måten:

Ja [lærer bedre nå], klart det altså. For da er du i ei gruppe der ferdighetsnivået er mye høyere, og du får lært mer avansert enn før. (...) I ordinære klasser kan du som regel det som undervises på tavla. Nå kan du lære ting du kanskje slet litt med og som du ikke fikk ordentlig gjennomgang på.

Uttalelsen til eleven i sitatet over viser et eksempel på tilpasningseffekten, som i tillegg til medeleveffekten, påvirket de høytpresterende elevenes opplevelse av trivsel og læring. Flere elever rapporterte at de fikk større faglige utfordringer i løpet av intervensjonsperioden, noe de fleste opplevde som positivt.

Endringene påvirket elevenes læringsmiljø. Elevene ble mer muntlig aktive, flere deltok i klasseromsdialogen, og elevene diskuterte mer seg i mellom. Dette kan illustreres med et utsagn fra en C-elev:

Og så får vi si meninga vår med en gang når hun [Mona] spør oss og sånt der. Før var det bare han [Frank] som sto på tavla og prata hele tida sånn der (...) Du får diskutert meningene dine mer da, sånn at det ikke er bare din mening som blir sagt.

Noen få elever beskrev læringsmiljøet i de prestasjonslike elevgruppene (i begynnelsen) som litt mindre trygt. Dette på grunn av endringer i det sosiale miljøet (for eksempel adskilt fra venner). Her er et eksempel på en uttalelse gitt av en C-elev:

Jeg vil si at det var kanskje hakket bedre når vi var i klassen og sånn, vi som kjenner hverandre og forstår hverandre litt bedre og sånn, men det er jo greit at vi sitter sånn nå og da, men jeg trivdes kanskje litt bedre når vi kjente de fleste.

Endringene i bruk av samtale ble ikke bare beskrevet som positive. Mange C-elever ga tilbakemelding om at Mona i løpet av intervensjonsperioden ga mindre respons på deres spørsmål og svar, noe som bidro til frustrasjon. En C-elev beskrev endringene i undervisningspraksis, og opplevelsen av disse, slik:

Ja [Mona sier aldri om det er rett eller feil], og da mister du på en måte entusiasmen til å se i boka og... Du vet at det stopper, det er bedre at læreren egentlig retter opp feilene dine, for da vet du feilene dine, og da har du mulighet for å rette de opp.

Denne frustrasjonen var ikke like stor hos alle C-elevene. Noen elever ga uttrykk for at det handlet om tilvenning, her eksemplifisert giennom stemmen til en av C-elevene: «Det var litt rart i starten, men nå begynner jeg å bli vant til det».

Ingen av D-elevene rapporterte om tilsvarende frustrasjon, men flere ga uttrykk for at de i løpet av intervensjonsperioden fikk flere muligheter til å utfordre egne ideer og tanker i dialog med medelever. En D-elev beskrev det på denne måten: «Vi snakker sammen i gruppa, så får vi vite de andre sitt syn på det og sånt. Ikke bare hva vi mener. For de ser kanskje saken fra en annen side». 


\section{Bård Knutsen}

Intervensjonenes effekt på selvoppfatning, motivasjon, trivsel og læring

Elevenes mestringsforventning ble målt i forkant av intervensjonsperioden. Dataene viser at elevenes mestringsforventning var positivt korrelert med elevenes prestasjonsnivå. I tillegg virker samlevariabelen å være læreravhengig. I begge prestasjonsgruppene rapporterte Monas elever om høyere gjennomsnittsskår enn Frank sine. Betydningen av lærertilhørighet virket å være særlig stor for de høyest presterende elevene (D-elevene).

Den samme tendensen kommer til syne i samlevariabelen selvvurdering. Monas elever rapporterte $\mathrm{i}$ forkant av intervensjonsperioden om høyere gjennomsnittlig selvvurderingsskår enn Frank sine. I løpet av intervensjonsperioden rapporterte derimot elevene som opprinnelig ble undervist av Frank, om økning i gjennomsnittlig selvvurderingsskår, mens endringen var tilnærmet uforandret for de øvrige elevene.

Elevenes indre motivasjon ble målt gjennom samlevariablene generell interesse og interessebasert motivasjon. I forkant av intervensjonsperioden var D-elevene mer indre motivert enn C-elevene. Intervensjonene virket å ha liten innvirkning på dette temaet, og i den grad det ble registrert endring, var tendensen negativ. Elevenes ytre motivasjonsprofil hadde mange likheter med elevenes indre motivasjon. D-elevene rapporterte om høyere ytre motivasjon enn C-elevene, og samlevariabelskårene endret seg lite i løpet av intervensjonsperioden.

De høytpresterende elevene rapporterte om generelt god trivsel og læring i sine opprinnelige klasser. Særlig gjaldt dette D-elever med lærerbytte, hvor alle elever rapporterte om nokså god eller svært god trivsel og læring i forkant av intervensjonsperioden. Analysene avdekket at intervensjonene påvirket elevenes opplevelse av trivsel og læring ulikt, både mellom og delvis innad de ulike prestasjonsgruppene. Celever med lærerbytte rapporterte om uforandret opplevelse av læring, men redusert trivsel, mens de uten lærerbytte rapporterte om både redusert trivsel og læring i løpet av intervensjonsperioden. D-elever med lærerbytte rapporterte om uforandret trivsel og læring i løpet av intervensjonsperioden, mens de uten lærerbytte rapporterte om økning.

Fokusgruppeintervjuene bekreftet inntrykket om at D-elevene var mer positive til intervensjonene enn C-elevene. Årsaken til misnøyen hos C-elevene ser ut til å være relatert til Monas undervisningsadferd. Det at hun var tilbakeholden med å gi svar og respondere på elevenes spørsmål og tilbakemeldinger, førte til frustrasjon hos elevene.

\section{Drofting}

Det er nærliggende å tenke at undervisningspraksis har betydning for effektene av nivådeling. De fleste lærere og beslutningstakere er enige om at selvregulerte elever lærer best (Boekaerts, 1997) og at skolen bør ha som mål å lære elevene selvregulerende ferdigheter. Renzulli og Renzulli (2010) viser til at induktiv læring er mer effektivt med tanke på å utvikle elevers begavelse enn mer tradisjonelle (deduktive) arbeidsformer. 
Datamaterialet i denne studien peker på tre forhold av særlig betydning for de høytpresterende elevenes opplevelse av og respons på overgang til prestasjonslike elevgrupper i naturfagundervisningen. Disse er:

1) Undervisningspraksis

2) Laringsmiljo

3) Elevenes selvoppfatning, motivasjon og opplevelse av trivsel og laring.

\section{Undervisningspraksis}

Elevene rapporterte om endret undervisningspraksis i løpet av intervensionsperioden. Det var særlig bruk av samtale og praktisk elevarbeid som økte. Utforsking av egne ideer, viste en mindre, men generell økning som var upåvirket av elevenes prestasjonsnivå og lærertilhørighet.

Collins og Gan (2013) beskriver to potensielle effekter av prestasjonslike elevgrupper: tilpasningseffekten og medeleveffekten. Tilpasningseffekten er knyttet til en potensiell effektivitetsgevinst for læreren. Ved overgang til prestasjonslike elevgrupper kan læreren konsentrere undervisningen mot en mindre kompleks elevgruppe, og lettere identifisere og møte læringsbehovene til den enkelte elev. Den andre effekten, medeleveffekten, er knyttet til kvaliteten på medelevene. Det er ofte positiv sammenheng mellom kvaliteten på medelevene og egne prestasjoner (Collins \& Gan, 2013), og høytpresterende elever vil derfor kunne tjene på å være i prestasjonslike elevgrupper.

Lærerne i denne artikkelen er i tidligere artikler av undertegnede, Knutsen (2015a) og Knutsen (2015b), blitt beskrevet som to ulike lærertypologier: Frank som fagtradisjonalist med lærersentrert undervisningsorientering og høy fagorientering, og Mona som moderne pedagog med elevsentrert undervisningsorientering og lavere fagorientering. Knutsen (2015a) hevder at Frank foretrakk å undervise høytpresterende elever, men hadde dårlig samvittighet for de lavere presterende elevene. Mona var derimot mer orientert mot de lavtpresterende elevene, men innforstått med at de høytpresterende også måtte få utfordringer.

I forkant av intervensjonsperioden rapporterte elevene om at Frank involverte Celevene mer enn D-elevene i de faglige samtalene, og at det motsatte var tilfellet for Mona. En mulig tolking kan være at Frank brukte de faglige samtalene som virkemiddel for å tilpasse undervisningen for de lavere presterende elevene, mens Mona brukte samtalene til å la de høytpresterende bli sett og hørt.

Ved inndeling i prestasionslike elevgrupper ble forskjellene $\mathrm{i}$ bruk av samtale tilsynelatende visket ut mellom prestasjonsgruppene. Dataene indikerer at elevenes opplevelse av mer samtale i naturfagundervisningen, og flere muntlig aktive elever, skyldes tilpasningseffekter. I prestasjonslike elevgrupper ser det ut til å være enklere for lærerne å involvere elevene i klasseromsdialogen. I fokusgruppeintervjuene fortalte elevene om økt muntlig aktivitet seg i mellom. Dette kan ha bidratt til positive medeleveffekter siden alle elevene var på et jevnere og høyere prestasjonsnivå enn hva tilfellet er i samholdte elevgrupper. 


\section{Bård Knutsen}

Økt bruk av praktiske elevaktiviteter er ikke ensbetydende med en mer utforskende naturfagundervisning (Knutsen, 2015b). Dataene tyder på at inndeling i prestasjonslike elevgrupper i liten grad påvirket elevenes frihetsgrader i timene. Elevenes muligheter for å utforske egne ideer ble i mindre grad endret i løpet av intervensjonsperioden, noe som tyder på at undervisningen forble like lærerstyrt som før. Det kan likevel, med utgangspunkt i elevresponsene, være grunn til å hevde at Mona i større grad enn Frank prøvde å utfordre elevene til å reflektere over og konstruere egen forståelse av fagstoffet før hun presenterte den naturvitenskapelige forklaringen.

Elevene opplevde økt bruk av praktiske elevaktiviteter som positivt, særlig C-elevene, fortrinnsvis fordi de syntes det var gøy og annerledes. Derimot var flere D-elever kritiske til økt og mye bruk av praktiske aktiviteter, og de etterlyste hjelp fra læreren til å koble teori og praksis. Hensikten med å implementere praktisk arbeid i naturfagundervisningen er å koble sammen den virkelige verden (objekter, materialer og hendelser) og de abstrakte teorier og ideer naturvitenskapen har å tilby som forklaringsmodeller (Knutsen, 2015b). Abrahams og Millar (2008) viser til at naturfaglærere ofte bare korrigerer og snakker med elevene om hva de gjør, eller ikke gjør, og i mindre grad kobler aktivitetene opp mot fagets abstrakte teorier og ideer. Aktiviteten blir en "gjøring" som i liten grad blir reflektert over, og derfor ikke støtter opp om arbeidet mot læringsmålene.

Det at lærerne i denne studien ikke knyttet aktivitetene tettere til teori, kan skyldes kort intervensjonsperiode. Ifølge Timperley, Wilson, Barrar og Fung (2007) tar endring av undervisningspraksis tid, og eventuelle effekter av pågående endringer $\mathrm{i}$ læreres undervisningspraksis er ikke nødvendigvis målbare hos elevene.

\section{Læringsmiljø}

Inndelingen i prestasjonslike elevgrupper påvirket elevenes læringsmiljø. Den kvalitative analysen avdekket at de høytpresterende elevene var positive til inndelingen i prestasjonslike elevgrupper. D-elevene rapporterte om mer arbeidsro, det ble lettere å få hjelp, alle bidro ved gruppearbeid, og elevene opplevde at det var lærerikt å drøfte fagstoffet med andre medelever.

Mange av elevutsagnene peker på at elevene opplevde samhandlingen og kommunikasjonen seg i mellom lettere, noe som tyder på at elevenes opplevelse av bedre læringsmiljø var mer et resultat av medeleveffekter enn tilpasningseffekter. Knutsen (2015a) hevder at lærerne, på grunn av ulik undervisnings- og fagorientering, hadde ulik didaktisk kompetanse. Blant annet ble det på grunnlag av Franks undervisningsorientering stilt spørsmål ved hans evne til å avdekke og møte elevers læringsbehov.

C-elevene rapporterte om flere av de samme medeleveffektene som D-elevene, men var lite fornøyd med Monas endringer i undervisningsadferd. De var frustrerte over at Mona ga lite respons, og at de måtte finne ut ting på egen hånd. Mona var mer endringsvillig og elevsentrert enn Frank (Knutsen, 2015a), noe som kan ha bidratt til at omlegging av undervisningspraksis skjedde for raskt. Lærerbytte, kombinert med at Mona allerede i utgangspunktet var mer induktivt orientert i sin undervisningsform enn Frank, kan ha hatt en forsterkende effekt på denne 
elevgruppens opplevelse av endret undervisningspraksis. Frustrasjonen kan ha vært en reaksjon på det elevene opplevde som et brudd på den didaktiske kontrakten (Blomhøj, 1994) da læreren endret til en mer dialogisk kommunikasjonsform. Elevenes ønske om og behov for tydelige tilbakemeldinger kan ha vært forankret i fagets egenart og elevenes forventninger om å få formidlet fagets kunnskapsgrunnlag. Dialogiske kommunikasjonsformer er i følge Scott (2008) egnet til å etablere undring og eierforhold til temaet, mens mer autoritative kommunikasjonsformer er best egnet til å formidle den naturvitenskapelige forståelsen.

\section{Elevenes selvoppfatning, motivasjon og opplevelse av trivsel og læring}

Selvoppfatning og motivasion har betydning for elevenes læring (Skaalvik \& Skaalvik, 2005). «Big-fish-little-pond»-effekten (BFLPE) peker på risikoen for redusert selvoppfatning og motivasjon ved inndeling av elever i prestasjonslike elevgrupper (Marsh, 1990). Analysene i denne studien avdekket ingen større endringer i elevenes selvoppfatning eller motivasjon. Skaalvik og Skaalvik (2005) viser til at selvoppfatning er et relativt stabilt personlighetstrekk, mens Preckel m.fl. (2010) hevder at eventuelle BFLP-effekter vil være størst $\mathrm{i}$ de ti første ukene. Ut fra dette burde eventuelle endringer $\mathrm{i}$ elevers selvoppfatning ha blitt påvist i løpet av intervensjonsperioden. Det er en mulighet for at bruk av gjennomsnittsverdier i analysene av det kvantitative datamaterialet har skjult enkeltelevers nedgang i selvoppfatning på grunn av andre elevers økning. Elevuttalelsene tyder derimot på at elevenes selvoppfatning ikke ble negativt påvirket av å være sammen med jevnbyrdige medelever, heller motsatt.

Et forhold med betydning for elevenes selvoppfatning er lærernes merking av elever som høytpresterende. Skaalvik og Skaalvik (2005) beskriver lærere som signifikante andre i elevers liv, med stor betydning for deres sosiale selvoppfatning. Lærerens rangering kan potensielt både styrke og true elevers selvoppfatning. Rangering som bekrefter eller overgår elevers egenvurdering vil kunne styrke selvoppfatningen, mens rangering som undergraver selvvurderingen vil være en trussel mot elevenes selvoppfatning.

Adams-Byers m.fl. (2004) viser til at en del høytpresterende elever foretrekker samholdte klasser da det er lettere å oppnå gode karakterer og være blant de beste $\mathrm{i}$ disse klassene uten å anstrenge seg. Den gjennomgående positive innstillingen til intervensjonen hos D-elevene kan tolkes som at Frank ikke utfordret D-elevene optimalt gjennom intervensjonsperioden. Det er i tilfelle i samsvar med konklusjonene i Knutsen (2015a) som peker på at Frank trivdes med å undervise selvdrevne elever og ikke utfordret dem optimalt. Frank var fornøyd med at elevene holdt planlagt progresjon. Ifølge Skaalvik og Skaalvik (2005) vil elever vurdere egne prestasjoner ut fra verbale og ikke-verbale reaksjoner fra mennesker rundt seg. D-elevenes opplevelse av at undervisningen i de prestasjonslike elevgruppene var mer avansert og bedre tilpasset deres behov, kan mer ha vært en følelse enn en realitet, forårsaket av det å tilhøre den høyest presterende elevgruppen, og en gruppe som læreren hadde store forventninger til. 


\section{Bård Knutsen}

C-elevene var gjennomgående mindre positive til intervensjonen, noe de blant annet signaliserte gjennom lavere skår for opplevelse av trivsel og læring. Mona utfordret i større grad elevene til å finne ut av ting selv, før hun responderte på deres spørsmål og innspill. Topland og Skaalvik (2010) peker på at det er sterk sammenheng mellom elevers opplevelse av å få faglig hjelp og støtte og deres mer emosjonelle opplevelse (trivsel) av forholdet til lærerne. Monas relativt omfattende og raske omlegging av undervisningspraksis kan ha gitt elevene inntrykk av at hun ikke støttet dem faglig, med redusert opplevelse av trivsel og læring som resultat. Elevers trivsel er sterkt relatert til deres motivasjon for skolearbeid (Topland \& Skaalvik, 2010) og kan være en forklaring til hvorfor heller ikke C-elevene rapporterte om økt motivasjon i løpet av intervensjonsperioden. Flere av C-elevene hevdet at den nye undervisningspraksisen var en tilvenningssak, noe som kan tyde på at resultatet av intervensjonene på sikt kunne blitt bedre.

\section{Konklusjon}

Denne studien viser hvordan høytpresterende tiendetrinns elever opplever og responderer på naturfagundervisning i prestasjonslike elevgrupper. To intervensjoner ble introdusert: inndeling av elever i prestasjonslike elevgrupper og overgang til mer elevaktiv og utforskende naturfagundervisning. Analysene avdekket tre forhold av særlig betydning for elevenes opplevelse av og respons på overgang til prestasjonslike elevgrupper i naturfagundervisningen. Disse var:

1) Undervisningspraksis

2) Laringsmiljø

3) Elevenes selvoppfatning, motivasjon og opplevelse av trivsel og laring.

Studien indikerer at overgang til en mer praktisk og elevaktiv undervisningspraksis ga elevene større handlingsrom for samarbeid, samt flere muligheter til å samtale om og utforske ulike sider ved faget og dets begreper. Dette kan beskrives som en medeleveffekt som kan gjøres mulig gjennom endringer i gruppesammensetning, undervisningspraksis og læreradferd. Det å være sammen med jevnbyrdige medelever kan bidra til mer jevn arbeidsfordeling elevene imellom, i tillegg til at de kan utfordre og hjelpe hverandre på sitt nivå gjennom mer og bedre samarbeid i de nye gruppene. Studien har ikke avdekket negative BFLP-effekter.

Det ble ikke påvist like tydelige tilpasningseffekter. Store endringer i undervisningspraksis i løpet av kort tid bidro tilsynelatende til at elevene følte den didaktiske kontrakten truet. Elevene responderte med å yte motstand mot endringene, og selvoppfatning, motivasjon og opplevelse av trivsel og læring ble negativt påvirket. Denne responsen kan imidlertid være av kortvarig karakter.

Faglig glød var en preferert læreregenskap hos de involverte elevene, og dette kan være en medvirkende faktor til at elevene foretrakk Frank som naturfaglærer. Imidlertid kan en lærersentrert undervisningspraksis medføre økt risiko for at naturfagundervisningen ikke blir tilpasset de høytpresterende elevenes læringsbehov. 
Utilstrekkelige faglige utfordringer kan forklare hvorfor de høyest presterende elevene, på tross av økt opplevelse av trivsel og læring, ikke rapporterte om større endringer i selvoppfatning og motivasjon i løpet av intervensjonsperioden.

I denne studien måtte halvparten av elevene bytte lærer, en intervensjon som tydeliggjorde lærerens betydning for elevers opplevelse av og responser på naturfagundervisning i prestasjonslike elevgrupper på ungdomstrinnet. Undervisningspraksis, samt læreres undervisnings- og fagorientering, er viktige elementer å ta hensyn til ved planlegging og gjennomføring av organisatorisk differensiering dersom høytpresterende elever skal oppleve og respondere positivt på ny læringskontekst.

Det var metodiske utfordringer knyttet til denne studien. To samtidige intervensjoner gjorde det vanskelig å peke på kausalitet, og studiens korte intervensjonsperiode gjorde det vanskelig å måle langsiktige effekter. Senere studier bør prøve å unngå dette ved å legge opp til lengre intervensjonsperioder og unngå lærerbytte.

\section{Biografi}

Bård Knutsen, er universitetslektor i biologifagdidaktikk ved Program for lærerutdanning, NTNU. Har bakgrunn som lærer og rektor i grunnskolen og naturfagambassadør ved Nasjonalt senter for naturfag i opplæringen (Naturfagsenteret). Har vært ansatt ved PLU/ NTNU siden 2007.

\section{Referanser}

Abrahams, I. \& Millar, R. (2008). Does Practical Work Really Work? A study of the effectiveness of practical work as a teaching and learning method in school science. International fournal of Science Education, 30(14), 1945-1969.

Adams-Byers, J., Whitsell, S. S. \& Moon, S. M. (2004). Gifted Students' Perceptions of the Academic and Social/ Emotional Effects of Homogeneous and Heterogenous Grouping. Gifted Child Quarterly, $48(1), 7-20$.

Birkemo, A. (2002). Laringsmiljø og utvikling. Universitet i Oslo, Pedagogisk forskningsinstitutt.

Blomhøj, M. (1994). Ett osynligt kontrakt mellan elever och lärare. Nämnaren, 4, 36-45.

Boekaerts, M. (1997). Self-regulated learning: A new concept embraced by researchers, policy makers, educators, teachers, and students. Learning and Instruction, 7(2), 161-186.

Brousseau, G. (1984). The crucial role of the didactical contract in the analysis and construction of situations in teaching and learning mathematics. Theory of mathematics education, 54, 110-119.

Collins, C. A. \& Gan, L. (2013). Does sorting students improve scores? An analysis of class composition. (National Bureau of Economic Research Working Paper 18848). Cambridge, MA: National Bureau of Economic Research.

Creswell, J. W. \& Clark, V. L. P. (2011). Designing and conducting mixed methods research (2. utg.). London: Sage.

Gagné, F. (2010). Motivation within the DMGT 2.0 framework. High ability studies, 21(2), 81-99.

Harter, S., Fischer, K. W., Harter, A. B. \& Serwator, R. (1999). The construction of the self: a developmental perspective. New York: Guilford Press.

Kjærnsli, M., Lie, S., Olsen, R. V. \& Roe, A. (2007). Tid for tunge løft. Oslo: Universitetsforlaget.

Knutsen, B. (2015a). Naturfaglæreres møte med prestasjonslike elevgrupper. I A. B. Emstad \& E. Angelo (Red.), Ledelse for laring $i$ mulighetenes skole (s. 211-240). Oslo: Cappelen Damm Akademisk.

Knutsen, B. (2015b). Utforskende arbeidsmåter i biologi. I P. v. Marion \& A. Strømme (Red.), Biologididaktikk (2. utg., s. 80-103). Oslo: Cappelen Damm Akademisk.

Kunnskapsdepartementet. (2010). Meld. St. 22 (2010-2011). Motivasjon - Mestring - Muligheter. Oslo: Kunnskapsdepartementet.

Marsh, H. W. (1990). Influences of internal and external frames of reference on the formation of math and English self-concepts. Fournal of Educational Psychology, 82(1), 107.

Pintrich, P. R. \& Schunk, D. H. (2002). Motivation in education: Theory, research, and applications (2. utg.). Upper Saddle River, NJ: Prentice. 


\section{Bård Knutsen}

Postholm, M. B. (2005). Kvalitativ metode: en innføring med fokus på fenomenologi, etnografi og kasusstudier. Oslo: Universitetsforlaget.

Preckel, F., Götz, T. \& Frenzel, A. (2010). Ability grouping of gifted students: Effects on academic self-concept and boredom. British fournal of Educational Psychology, 80, 451-472.

Renzulli, J. S. \& Renzulli, S. R. (2010). The schoolwide enrichment model: A focus on student strengths and interests. Gifted Education International, 26(2-3), 140-156.

Rimm, S. B. (2008). Why Bright Kids Get Poor Grades and What You Can Do about it (3. utg.). Scottsdale: Great Potential Press, Inc.

Rosenberg, M. (1979). Conceiving the self. New York: Basic Books.

Scott, P. (2008). Talking a Way to Understanding in Science Classrooms. I N. Mercer \& S. Hodgkinson (Red.), Exploring talk in schools (s. 17-36). London: SAGE.

Skaalvik, E. M. \& Skaalvik, S. (2005). Skolen som laringsarena: selvoppfatning, motivasjon og laring. Oslo: Universitetsforlaget.

Timperley, H., Wilson, A., Barrar, H. \& Fung, I. (2007). Teacher professional learning and development: Best Evidence Synthesis Iteration. Hentet fra http://www.oecd.org/edu/school/48727127.pdf

Topland, B. \& Skaalvik, E. M. (2010). Meninger fra klasserommet: analyse av Elevundersøkelsen 2010. Kristiansand: Oxford Research.

Utdannings- og forskningsdepartementet. (2003). I første rekke - Forsterket kvalitet $i$ en grunnopplcering for alle. (NOU 2003: 16). Hentet fra http://www.regjeringen.no/Rpub/NOU/20032003/016/PDFS/NOU2003 20030016000DDDPDFS.pdf 